\title{
MENINGKATKAN STATUS GIZI BALITA MELALUI PRAKTEK PENGOLAHAN MAKANAN PENDAMPING ASI BUATAN SENDIRI
}

\author{
Mitra" $^{* 1}$, Winda Septiani ${ }^{2}$, Herlina Susmaneli ${ }^{3}$ dan Nurlisis ${ }^{4}$ \\ ${ }^{1,4}$ Program Studi Magister Kesehatan Masyarakat STIKes Hang Tuah Pekanbaru \\ ${ }^{2,3}$ Program Studi Sarjana Kesehatan Masyarakat, STIKes Hang Tuah Pekanbaru \\ *e-mail: mitra@ $\underline{\text { htp.ac.id }}{ }^{1}$, magisterwinda@gmail.com ${ }^{2}{ }_{2}$ neli herlina@yahoo.co.id ${ }^{3}$, nurlisis@ @tp.ac.id $^{4}$
}

\begin{abstract}
The provision of complementary foods is still an issue, especially malnourished children. Data from Umban Sari Community Health Centre shows that there are 37 under-five children with malnutrition status. The purpose of community service is to increase the knowledge and skills of mothers who have malnourished children in processing homemade complementary feedings. The service method is nutrition counseling and the practice of complementary feeding. Participants were 5 cadres and 15 mothers. Location of Community Service in the Sri Meranti Integrated Healthcare Center in the Work Area of Umban Sari Health Centre. The results showed that participants enthusiastically attended counseling and cooking demonstrations, as indicated by many questions from participants. Complementary feedings are processed according to the tastes of toddlers so that it is expected to improve the nutritional status of children. Cadres are expected to guide mothers of children under five in processing food according to the needs of toddlers to reduce the prevalence of malnutrition.
\end{abstract}

Keywords: Toddler, underweight, Breastfeeding complementary foods, Homemade

\section{Abstrak}

Praktek Pemberian makanan pendamping ASI masih menjadi permasalahan, terutama pada balita gizi kurang. Data Puskesmas Umban Sari menunjukkan terdapat 37 balita berstatus gizi kurang. Tujuan Pengabdian kepada masyarakat adalah untuk meningkatkan pengetahuan dan keterampilan ibu yang memiliki balita gizi kurang dalam pengolahan makanan pendamping ASI buatan sendiri. Metode pengabdian berupa penyuluhan gizi dan praktek pembuatan makanan pendamping ASI. Peserta adalah 5 orang kader posyandu dan 15 ibu balita gizi kurang. Pengabdian masyarakat dilaksanakan di Posyandu Bawah Garis Merah (BGM) Sri Meranti Wilayah Kerja Puskesmas Umban Sari. Hasil menunjukkan bahwa peserta antusias dalam mengikuti penyuluhan dan demonstrasi masak, ditunjukkan dengan banyaknya pertanyaan dari peserta. Makanan Pendamping ASI yang diolah sesuai dengan selera bayi dan balita, sehingga diharapkan dapat meningkatkan status gizi balita. Setelah kegiatan pengabdian ini, diharapkan kader dapat membimbing ibu balita dalam hal pengolahan makanan sesuai dengan kebutuhan balita untuk menurunkan prevalensi gizi kurang.

Kata kunci: Balita, Gizi Kurang, Makanan Pendamping ASI, Buatan Sendiri

\section{PENDAHULUAN}

Status gizi merupakan salah satu indikator yang digunakan untuk mengetahui pertumbuhan seorang anak. Saat ini Indonesia mengalami 3 masalah gizi utama yang harus segera di atasi yaitu stunting (pendek), underweight (gizi kurang) dan wasting (kurus) (International Food Policy Research Institute, 2014). Prevalensi ketiga status gizi tersebut berada pada diatas ambang batas yang ditentukan oleh WHO, yaitu 20\% untuk stunting, $5 \%$ untuk wasting dan underweight (Kemenkes RI, 2017). Hasil Riskesdas 2018 untuk kota Pekanbaru menunjukkan bahwa prevalensi gizi kurang dan buruk pada balita adalah 15,3\% (Kementerian Kesehatan RI, 2018). Dibandingkan Riskesdas tahun 2013 menunjukkan prevalensi tersebut turun, tetapi masih di atas ambang batas yang ditetapkan oleh WHO.

Kekurangan gizi pada balita berdampak jangka panjang pada produktivitas dan kualitas hidup anak kedepannya (Kusmiyati, Purnamaningrum, Nugrahaeni, \& Ronoadmodjo, 2017). Pemantauan status gizi balita berguna untuk mengetahui kekurangan atau kelebihan gizi pada masa balita. Pemantauan status gizi dilakukan setiap bulannya di Posyandu. Wilayah Kerja Puskesmas Umban Sari Kota Pekanbaru, terdapat posyandu khusus untuk balita di bawah garis merah (Posyandu BGM) yaitu Posyandu Sri Meranti. Berdasarkan laporan puskesmas Umban Sari tahun 2016 terdapat 37 balita gizi kurang. Sampai Desember 2016, 6 balita sudah berstatus gizi normal dan 18 balita masih berstatus gizi kurang, satu diantaranya adalah gizi buruk. Tiga belas balita tidak dapat terpantau lagi karena tidak aktif datang ke posyandu. Pada Tahun 2017 masih 28 balita gizi kurang. 
Kurang gizi pada balita disebabkan oleh berbagai faktor yaitu faktor langsung dan faktor tidak langsung. Faktor langsung adalah asupan gizi dan penyakit infeksi. Faktor tidak langsung antara lain adalah pelayanan kesehatan, pola pengasuhan, pengetahuan ibu dan status ekonomi (Supariasa, 2014). Ibu sebagai pengasuh utama balita sangat berperan dalam pemberian makanan pada balita. Pengetahuan ibu yang rendah dalam menentukan jenis dan jumlah makanan yang dikonsumsi balita berakibat tidak cukupnya asupan gizi yang diberikan kepada balita dan menyebabkan kekurangan gizi pada balita (Sari \& Ratnawati, 2018). Penelitian yang dilakukan Mitra, Nurlisis dan Destriani (2018) menunjukkan bahwa sebesar $52,7 \%$ balita hanya mengonsumsi 4 sampai 5 jenis bahan makanan dan 18,0 \% mengonsumsi kurang dari 3 jenis bahan makanan (Mitra, Nurlisis, \& Destriani, 2018). Hal ini menunjukkan bahwa makanan yang dikonsumsi balita belum beragam.

Kualitas dan kuantitas makanan pendamping ASI sangat menentukan status gizi balita. Untuk itu ibu perlu diberikan pengetahuan dan keterampilan dalam mengolah makanan dengan memperhatikan kualitas dan kuantitas dari makanan pendamping ASI tersebut. Kualitas dilihat dari jenis dan keberagaman makanan, sedangkan kuantitas dilihat dari frekuensi pemberian makanan. Berkaitan dengan hal tersebut maka dilakukan kegiatan pengabdian kepada masyarakat yang melibatkan ibu balita gizi kurang dalam membuat makanan pendamping ASI yang bergizi dan beragam. Tujuan Pengabdian kepada masyarakat adalah untuk meningkatkan pengetahuan dan keterampilan ibu balita gizi kurang dalam mengolah makanan pendamping ASI buatan sendiri.

\section{METODE}

Metode pengabdian dilakukan dalam bentuk penyuluhan gizi berupa penyusunan menu makanan balita dan praktek pembuatan makanan pendamping ASI serta penimbangan berat badan dan pengukuran tinggi badan balita. Pengabdian Masyarakat ini merupakan tindak lanjut dari kegiatan Penelitian yang dilakukan oleh Mitra dkk dengan judul Model Pendidikan Gizi untuk mencapai pertumbuhan optimal pada Bayi dengan Berat Badan Lahir Rendah. Kegiatan Pengabdian Kepada Masyarakat dilaksanakan di Posyandu BGM (Bawah Garis Merah) Sri Meranti Wilayah Kerja Puskesmas Umban Sari Kota Pekanbaru Provinsi Riau. Waktu Pengabdian kepada masyarakat diadakan pada tanggal 22 Februari 2018. Sebelum kegiatan dilakukan tim pengabdi menemui pimpinan Puskesmas untuk meminta izin untuk diadakannya pengabdian Kepada Masyarakat, menghubungi kader dan memberikan undangan kepada ibu balita gizi kurang untuk hadir pada kegiatan pengabdian kepada masyarakat. Peserta pengabdian kepada masyakat adalah 5 (lima) orang kader posyandu dan 15 (lima belas) ibu beserta balita gizi kurang. Data balita gizi kurang diperoleh dari Posyandu BGM Sri Meranti yang berjumlah 37 balita gizi kurang. Tidak semua balita gizi kurang dapat hadir pada kegiatan pengabdian masyarakat ini, hanya 15 orang ibu beserta balita gizi kurang yang hadir. Bahan yang digunakan dalam pembuatan makanan pendamping ASI adalah bahan yang mudah diperoleh masyarakat dengan harga yang terjangkau seperti tahu, telur dankacang merah. Peralatan masak yang digunakan dipinjam dari peserta, seperti panci dan kompor gas. Peralatan yang digunakan untuk penyuluhan gizi merupakan media peraga pendidikan gizi pada penelitian Mitra,dkk berupa alat peraga penyusunan menu dan kurva pertumbuhan dari WHO (Mitra, Susmaneli, \& Winda Septiani, 2017). Pengabdi juga membagikan buku Kumpulan Resep makanan pendamping ASI kepada peserta pengabdian. Buku Kumpulan Resep makanan pendamping ASI ini disusun oleh Pengabdi dengan harapan peserta dapat mempraktekkan menu yang telah diajarkan di rumah

\section{HASIL DAN PEMBAHASAN}

Kegiatan pengabdian kepada masyarakat berlangsung dengan baik dan lancar. Hal ini dapat dilihat dari antusias peserta dinilai cukup baik dengan banyaknya pertanyaan yang diberikan kepada pengabdi. Peserta mengikuti kegiatan sampai dengan selesai. Kegiatan pengabdian masyarakat dimulai pada pukul 08.30 dan berakhir pukul 12.00. Kegiatan dimulai dengan penimbangan berat badan dan tinggi badan balita, Penyampaian materi tentang Penyusunan menu balita dengan menggunakan alat peraga dari hasil penelitian Mitra, dkk (2017) dan diakhiri dengan praktek pembuatan makanan pendamping ASI. Hasil olahan makanan pendamping ASI kemudian dibagikan kepada balita untuk di konsumsi. Hasil pengamatan menunjukkan bahwa balita menyukai makanan yang dibagikan tersebut. 
Materi penyuluhan yang diberikan kepada balita adalah penyusunan menu pada kelompok umur 6-9 bulan, 9-12 bulan dan di atas 12 bulan. Penyusunan menu dengan memperhatikan usia balita, tekstur, warna dan rasa makanan, serta variasi jenis bahan makanan yang digunakan. Dalam penyampaian materi dan praktek pembuatan makanan pendamping ASI, pengabdi dibantu oleh beberapa orang mahasiswa. Kader posyandu juga berperan dalam kegiatan pengabdian kepada masyarakat ini. Peran kader adalah mengajak ibu balita gizi kurang untuk datang pada kegiatan pengabdian. Kader Posyandu berperan aktif dalam penimbangan balita dan pencatatan/pengisian Katu Menuju Sehat (KMS) dan sangat dekat dengan masyarakat di sekitar area posyandu (Sumardilah, Rahmadi, \& Rusyantia, 2018). Oleh karena itu kader posyandu sangat membantu pengabdi untuk mengkoordinir kegiatan pengabdian antara lain adalah menghubungi ibu balita, menyiapkan tempat, dan peralatan masak bersama dengan peserta/ibu balita. Hasil penelitian tentang Peran Kader dalam Pemantauan Pertumbuhan Balita di Posyandu BGM (Bawah Garis Merah) oleh Yunita \& Nurlisis didapat hasil bahwa kader cukup menjalankan perannya sebagai penghubung antara petugas kesehatan (bidan) dengan masyarakat, yaitu dengan melaporkan kepada petugas kesehatan bahwa ditemukan balita BGM serta merujuknya ke posyandu BGM ataupun ke puskesmas untuk diperiksa dan konsultasi kesehatan (J. Yunita \& Nurlisis, 2017).

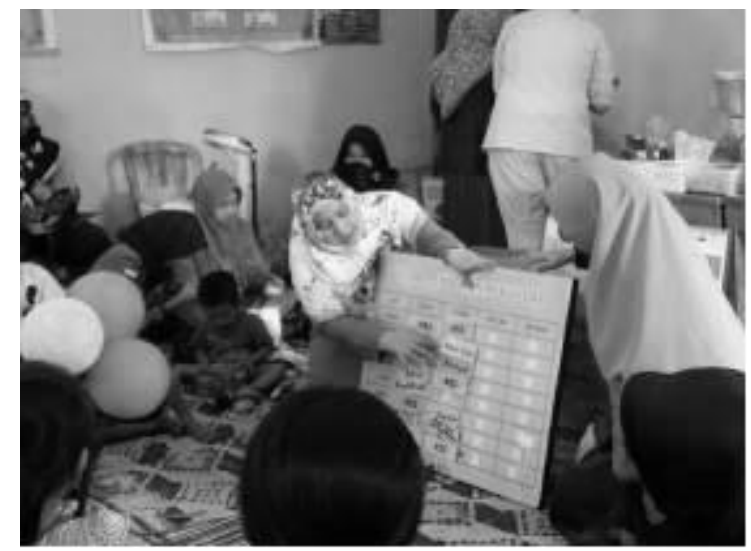

(a)

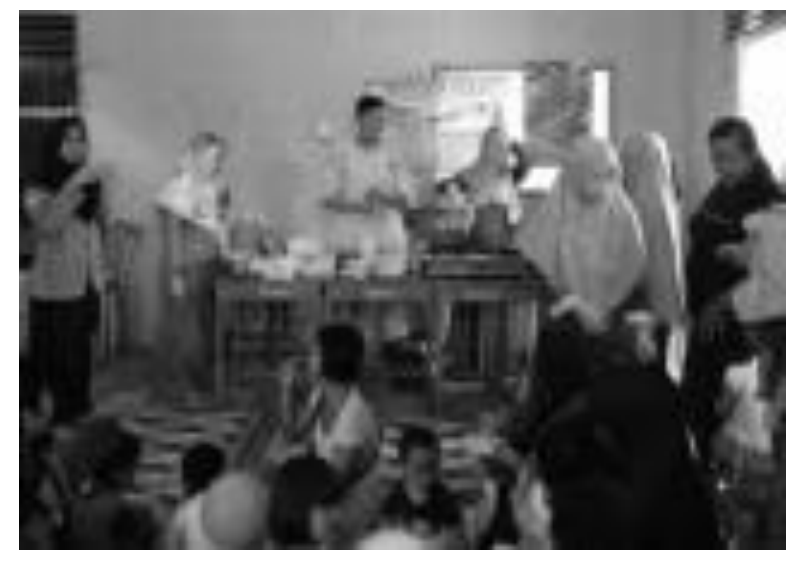

(b)

Gambar 1. Penyampaian Materi Penyusunan Menu balita (a), Demontrasi Pembuatan MP-ASI (b)

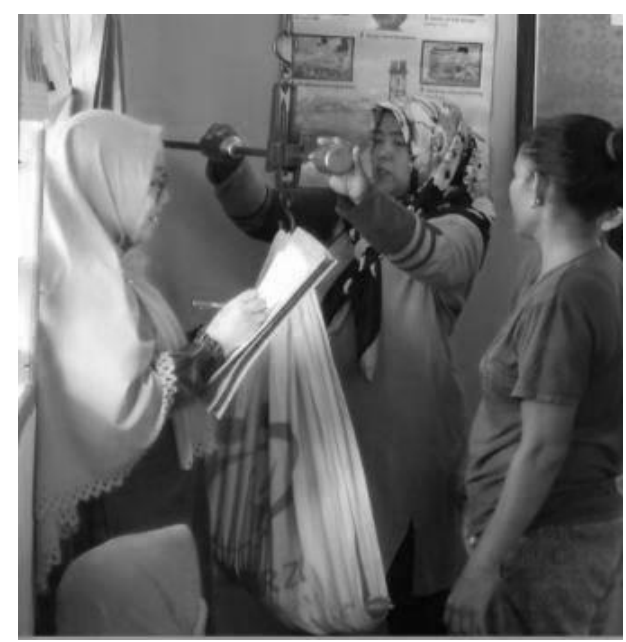

(a)

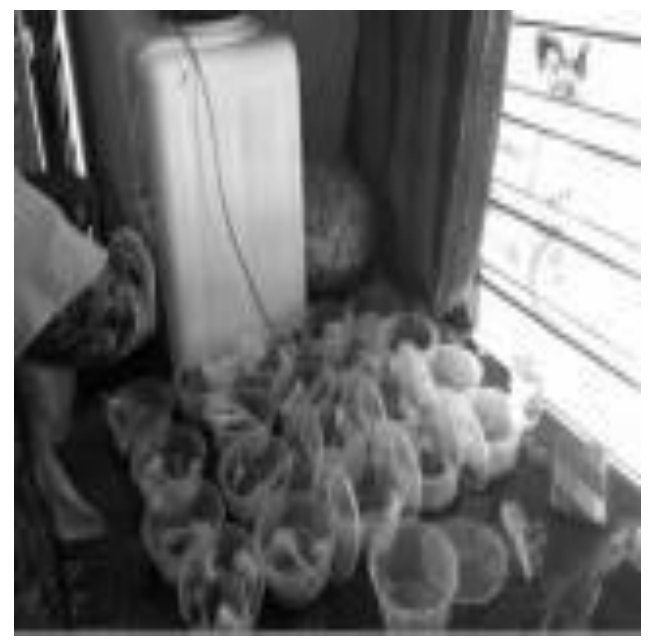

b)

Gambar 2. Penimbangan berat badan balita (a) dan MP ASI yang telah siap diolah (b)

Evaluasi kegiatan pengabdian masyarakat selain dilihat dari antusias dan kehadiran peserta juga dilihat dari hasil pretest dan posttest. Hasil pretest dan posttest menunjukkan bahwa rata-rata nilai 
pretest adalah 6,4 sedangkan posttest adalah 8,7. Dengan kata lain ada peningkatan pengetahuan sebesar 2,3 point.

Tabel 1. Hasil Pretest dan PosttTest 15 orang peserta tentang MP ASI

\begin{tabular}{cccc}
\hline Peserta & Pretest & Posttest & selisih \\
\hline 1 & 5 & 10 & 5 \\
2 & 5 & 8 & 3 \\
3 & 2 & 6 & 4 \\
4 & 7 & 8 & 1 \\
5 & 7 & 10 & 3 \\
6 & 7 & 8 & 1 \\
7 & 7 & 10 & 3 \\
8 & 5 & 7 & 2 \\
9 & 7 & 10 & 3 \\
10 & 8 & 10 & 2 \\
11 & 8 & 8 & 0 \\
12 & 8 & 10 & 2 \\
13 & 6 & 10 & 4 \\
14 & 6 & 8 & 2 \\
15 & 8 & 8 & 0 \\
\hline Rata-rata & $\mathbf{6 , 4}$ & $\mathbf{8 , 7}$ & $\mathbf{2 , 3}$
\end{tabular}

Peserta pengabdian kepada masyarakat adalah ibu balita gizi kurang. Ketika berlangsung kegiatan pengabdian baik penyampaian materi maupun praktek pembuatan makanan pendamping ASI, maka diharapkan ibu fokus pada materi yang diberikan. Untuk menghindari hal-hal yang menganggu dalam penyampaian materi seperti kegaduhan akibat balita yang menangis, tidak mau diam, maka pengabdi telah menyediakan mainan untuk mengalihkan perhatian balita dan dibantu oleh mahasiswa dalam mengawasi balita.

Menu yang dipraktekkan pada pengabdian ini tidak mahal, disesuaikan dengan kondisi ekonomi peserta. Makanan yang disajikan tidak harus mahal tetapi dapat memenuhi kebutuhan gizi anak dan seimbang. Variasi makanan baik dari segi komposisi, tekstur dan warna perlu diperhatikan, sehingga tampilan makanan menjadi menarik dan anak tertarik untuk mengkonsumsi makanan yang disajikan oleh ibunya. MP-ASI harus mengandung zat gizi sesuai kebutuhan. Untuk itu, diperlukan pengetahuan dan keterampilan ibu untuk menyediakan MP-ASI yang tepat dan bermutu sesuai dengan kemampuan dan ketesediaan bahan makanan setempat. Beberapa persyaratan pembuatan MP-ASI yang perlu diperhatikan adalah (1) Bahan makanan mudah diperoleh; (2) Mudah diolah; (3) Harga terjangkau; (4) Dapat diterima sasaran dengan baik; (5) Kandungan zat gizi memenuhi kecukupan gizi sasaran; (6) Mutu protein dapat memacu pertumbuhan fisik; (6) Jenis MP-ASI disesuaikan dengan umur sasaran; (7) Bebas dari kuman penyakit, pengawet, pewarna, dan racun; dan (8) Memenuhi nilai sosial, ekonomi, budaya, dan agama (Yuliarti, 2010).

Kurangnya pengetahuan dan kesadaran ibu tentang jumlah makanan, jenis dan waktu pemberian makanan yang tepat memberikan kontribusi terhadap status gizi balita. Studi National Nutrition Monitoring Bureau menunjukkan bahwa memberikan kontribusi yang signifikan terhadap status gizi kurang pada anak-anak bahkan pada keluarga yang sudah dapat memenuhi kebutuhan makanan seharihari (National Institute of Nutrition, 2013). Praktek pemberian makanan yang tidak pantas, seperti pengenalan makanan terlalu dini praktek pemberian makanan tambahan yang tidak pantas, pembatasan dalam pemilihan makanan dan jumlah yang cukup pelengkap makanan, telah diidentifikasi sebagai salah satu penyebab utama kekurangan gizi pada anak-anak di negara berkembang (Bhandari, Mazumder, Bahl, Martines, \& Black, 2004; Dewey, 2001). Hasil pengabdian kepada masyarakat menyatakan bahwa ibu balita yang mendapatkan pengetahuan tentang MP ASI dan beberapa contoh pengolahan menu MP ASI dapat menerapkannya dirumah (F. A. Yunita, Eka, \& Yuneta, 2019). Pemberian KIE (Komunikasi, informasi dan edukasi) dan praktik langsung yang diberikan kepada ibu dapat meningkatkan pengetahuan dan keterampilan ibu pada kelompok pendukung ASI (Alyensi \& 
Laila, 2019). Dengan dilakukannya pengabdian kepada masyarakat dalam bentuk pemberian edukasi kepada ibu balita dalam mengolah menu MP-ASI maka akan meningkatkan pengetahuan dan keterampilan ibu dalam mengolah MP-ASI sehingga dapat meningkatkan status gizi balita.

\section{KESIMPULAN}

Kegiatan pengabdian kepada masyarakat berlangsung dengan lancar dan baik. Peserta pengabdian adalah kader dan ibu balita gizi kurang.. Antusias peserta cukup baik dibuktikan dengan kehadiran peserta dan tanya jawab yang diberikan serta peserta mengikuti kegiatan pengabdian sampai selesai. Hasil pretest dan posttest menunjukkan adanya peningkatan pengetahuan ibu tentang makanan Pendamping ASI. Untuk meningkatkan status gizi balita maka diharapkan kepada ibu untuk menindaklanjuti dengan menerapkan menu seimbang pada balita. Kader dapat memberikan bimbingan kepada ibu dalam menyusun menu makanan sesuai dengan umur balita dengan menu yang bervariasi dalam jenis dan komposisi dan tidak mahal sehingga dapat meningkatkan selera makan balita, yang tentunya diharapkan dapat memperbaiki status gizi balita dari gizi kurang menjadi gizi baik. Pembinaan yang berkelanjutan juga diperlukan bagi kader sehingga lebih memahami dalam pemberian makanan yang berkualitas bagi keluarga. Kegiatan ini dapat dilakukan secara rutin dan berkesinambungan.

\section{UCAPAN TERIMA KASIH}

Penulis mengucapkan terima kasih kepada Ketua STIKes Hang Tuah Pekanbaru dan Yayasan Hang Tuah Pekanbaru yang telah memberi dukungan financial terhadap kegiatan pengabdian ini.

\section{DAFTAR PUSTAKA}

[1] Alyensi, F., \& Laila, A. (2019). Pembentukan dan Pelaksanaan Kelompok Pendukung ASI (KP ASI) di RW 2 Kelurahan Sialang Sakti Wilayah Kerja Puskesmas Rejosari Kecamatan Tenayan Raya Pekanbaru Tahun 2019. Dinamisia-Jurnal Pengabdian Kepada Masyarakat, 3(2), 299-304.

[2] Bhandari, N., Mazumder, S., Bahl, R., Martines, J., \& Black, R. E. (2004). An Educational Intervention to Promote Appropriate Complementary Feeding Practices and Physical Growth in Infants and Young Children in Rural Haryana , India. Jurnal Nutrition, 134(1), 2342-2348. https://doi.org/10.1093/jn/134.9.2342

[3] Dewey, K. (2001). The challenges of promoting optimal infant growth. The Journal of Nutrition, 131, 1879-1880. Retrieved from http://jn.nutrition.org/content/131/7/1879.short

[4] International Food Policy Research Institute. (2014). Global Nutrition Report 2014: Action and Accountability to Accelerate The World's Progress on Nutrition. Washington DC.

[5] Kemenkes RI. (2017). Hasil Pemantauan Status Gizi (PSG) 2016. Biro Komunikasi dan Pelayanan Masyarakat. Retrieved from http://sehatnegeriku.kemkes.go.id/baca/rilismedia/20170203/0319612/inilah-hasil-pemantauan-status-gizi-psg-2016/

[6] Kementerian Kesehatan RI. (2018). Hasil Utama Riskesdas Provinsi Riau 2018.

[7] Kusmiyati, Y., Purnamaningrum, Y. E., Nugrahaeni, I. K., \& Ronoadmodjo, S. (2017). The Effect of Malnutrition on The Quality of Life of Children Aged 2-4 in Indonesia. International Journal of Scientific Research and Education, 05(05), 6425-6430.

[8] Mitra, M., Nurlisis, N., \& Destriani, R. (2018). Jenis dan Keberagaman Makanan Pendamping Air Susu Ibu dengan Kejadian Stunting pada Anak Usia 6-24 bulan. Prosiding Widya Karya Pangan Dan Gizi, 1(1), 111-119.

[9] Mitra, M., Susmaneli, H., \& Winda Septiani. (2017). Model Pendidikan Gizi untuk mencapai Pertumbuhan Optimal pada Bayi Berat Badan Lahir Rendah. STIKes Hang Tuah Pekanbaru.

[10] National Institute of Nutrition. (2013). Diet and Nutritional Status of Rural Population, Prevalence of Hypertention \& Diabetes among Adults and Infant Young Child Feeding Practices. India. 
[11] Sari, M. R. N., \& Ratnawati, L. Y. (2018). Hubungan Pengetahuan Ibu tentang Pola Pemberian Makan dengan Status Gizi Balita di Wilayah Kerja Puskesmas Gapura Kabupaten Sumenep. Amerta Nutrition, 2(2), 182-188. https://doi.org/10.20473/amnt.v2.i2.2018.182-188

[12] Sumardilah, D. S., Rahmadi, A., \& Rusyantia, A. (2018). Pelatihan Pembuatan MP-ASI WHO Berbasis Pangan Lokal Bagi Kader Posyandu dan Ibu Baduta di Desa Sidosari. Sakai SambayanJurnal Pengabdian Kepada Masyarakat, 2(2), 69-73.

[13] Supariasa, I. D. N. (2014). Pendidikan \& Konsultasi Gizi. Jakarta: Penerbit Buku Kedokteran EGC.

[14] Yuliarti, N. (2010). Keajaiban ASI-Makanan Terbaik Untuk Kesehatan, Kecerdasan, dan Kelincahan Si Kecil. Yogyakarta: Andi Offset.

[15] Yunita, F. A., Eka, A., \& Yuneta, N. (2019). Model Pemberdayaan Ibu Balita Tentang MP-ASI di Kelurahan Wonorejo Kabupaten Karanganyar. Placentum Jurnal Ilmiah Kesehatan Dan Aplikasinya, 7(1), 14-18.

[16] Yunita, J., \& Nurlisis. (2017). Peran Kader dalam Pemantauan Pertumbuhan Balita di Posyandu BGM : Studi Kualitatif, Pekanbaru. Pekanbaru: STIKes Hang Tuah Pekanbaru. 